\title{
IS AFRIKAANS A SUITABLE MODEL IN PLANNING THE DEVELOPMENT OF AFRICAN LANGUAGES?
}

\author{
Stanley G M Ridge \\ University of the Western Cape
}

The repeated claim that Afrikaans provides a useful model for planning the development of the African languages is examined critically in this article with a view to elucidating important issues in South African language planning. The first part acknowledges the fascination of a language which has developed so fast for all domains of use, before examining the factors which drove that development, identifying particularly its affinity to Dutch and its tempestuous political and social history as making it a deceptive model for African languages. The second part explores some aspects of its history which do suggest valuable perspectives for other languages at this stage of our history. The examples discussed are language medium in schooling, the dangers of loss of confidence in a language considered with the possibilities of effective status interventions, and the complex issues surrounding language standards. The third part briefly examines the history of Afrikaans's ambiguous relation to English. It notes the persistence of the English 'enemy' metaphor along with a practical demand for English, considers the racial politics of the statutory equality debate at the time of Union, and analyses three distortions occasioned by an ambiguous attitude to English in a contemporary discussion of the role of Afrikaans. Finally, the notion of a model or example is itself questioned. The article proposes developing a deeper understanding of actual needs and attitudes in an ongoing process of language planning as the most likely way of doing justice to all South Africa's languages.

Die herhaalde aanspraak dat Afrikaans 'n bruikbare model bied waarvolgens die ontwikkeling van Afrika-tale beplan kan word, word in hierdie artikel krities ondersoek met die oog daarop om belangrike vraagstukke in die Suid-Afrikaanse taalbeplanning toe te lig. Die eerste deel gee erkenning aan die bekoring van 'n taal wat op alle gebruiksterreine baie vinnig ontwikkel het, voordat die faktore wat aan daardie ontwikkeling stukrag verleen het, van nader bekyk en die verwantskap met Nederlands in die besonder aangedui word, asook die stormagtige politieke en sosiale geskiedenis wat dit 'n misleidende model vir Afrika-tale maak. Die tweede deel verken sekere aspekte van die taal se geskiedenis waaruit op hierdie stadium van ons geskiedenis waardevolle perspektiewe vir ander tale na vore kom. Die voorbeelde wat bespreek word, is taalmedium in skole, die gevare van 'n gebrek aan vertroue in 'n taal met inagneming van die moontlikhede van effektiewe intervensies in die posisie daarvan, en die komplekse vraagstukke wat betref taalstandaard. Die derde deel bekyk kortliks die geskiedenis van Afrikaans se verwarrende verhouding met Engels. Dit skets die volharding van die "vyandelike" Engelse metafoor tesame met 'n vraag in die praktykna Engels, gee aandag aan die rassepolitiek van die debat oor statutêre gelykheid ten tye van die Unie, en ontleed in 'n kontemporêre bespreking oor die rol van Afrikaans drie wanvoorstellinge wat deur die dubbelsinnige houding teenoor Engels teweeg gebring is. Laastens word teen die idee van ' $n$ model of voorbeeld self beswaar gemaak. Die artikel stel die ontwikkeling van 'n dieper begrip van ware behoeftes en houdings in 'n deurlopende taalbeplanningsproses voor as die geskikste manier om aan al die tale in SuidAfrika reg te laat geskied. 
Afrikaans is a navolgbare voorbeeld vir die gebruikers van Afrikatale betreffende die ontwikkeling van hul taal. (Van Rensburg 1997: 97).

'Afrikaans is an example which may be followed by users of African languages concerning the development of their languages." This statement in the recent book, Afrikaans in Afrika, represents a strong (and I think hitherto unquestioned) strand of received wisdom in discussion of language planning issues in South Africa. Afrikaans is presented as a model or example useful in planning the development of African languages. That proposition must be scrutinised carefully.

The history of Afrikaans is fascinating. So rapid a trajectory from pidgin to creole to independent language in communion with its major ancestor and operative in all domains of use is immensely appealing, not least to linguists. Language planners have much to learn from this history, both as to what is profitable and as to what paths might be unfortunate to follow. However, it must be clear from the start that any offer of Afrikaans as a general model for the development of African languages will inevitably be misleading. The conditions shaping the development of Afrikaans differ too widely from the conditions of the African languages of South Africa for any simple analogy to be valid. These are the reasons:

First, Afrikaans could develop fast to meet most of the demands of modern life because it had Dutch in its hinterland. Dutch provided the lexis and the discourses for higher domain uses in a modern society. In most cases a few orthographic changes were all that was necessary to develop a new Afrikaans word from Dutch. One could argue that, in a globalising world, languages needing such resources have generally adopted what they have needed from other, not necessarily related, languages anyway. Fair enough. However, the discourses are another and much more complex matter. They mediate shared and tested understandings about the decorum and discipline necessary for higher-domain functions. In moving to Afrikaans as its main medium in 1924, the Dutch Reformed Church (NGK) had ready to hand the discursive heritage necessary to sustain its understood functions. The same could be said for the courts, parliament and the universities. However, shifting from one language to another very closely related to it, within a community already sharing the body of implicit assumptions encoded in the first language's prevailing discourses, is relatively unproblematic, and will often be a matter of verbatim translation. Moving to a new language from a culture relatively removed from it is quite another matter.

Let me be quite plain: I am not for a moment suggesting that the African languages and cultures lack rich resources of decorum or discipline - some of which may be vital sources of renewal in a common society perhaps still unduly bound by the linear thinking heritage of the 18 th century European Enlightenment. Nor am I suggesting that the current state of affairs in the institutions I have mentioned is close to being the best of all possible worlds. There are huge equity challenges in access to justice, politics and education in South Africa. However, I would argue very strongly that the embedded conventions of decorum and discipline which sustain these higher domain functions are complex and that it is dangerous to ignore them, as proponents of an instrumental view of language are prone to do. Languages cannot be used as counters. Insights from the linguistic sub-discipline of pragmatics have to augment what critical linguistics reveals in negotiating this territory.

The second reason for resisting a simple analogy of Afrikaans and the African languages - an unqualified use of Afrikaans as a model for development - is the great differences in the social, political and economic circumstances involved. Some of the appealing and useful similarities 
between Afrikaans and the African languages will be discussed later. For the moment, I have to assert the large areas that users of the languages do not have in common. The establishment of Afrikaans was a product of single-minded political will, accompanied increasingly by social, political and economic power in the speech community. Again let me be plain. My focus is not on Afrikaans as the language of the oppressor. In apartheid times, the black majority of Afrikaans-speakers was indeed oppressed, but Afrikaans was used (and continues to be used) by many of them as a vital and effective language of liberation - Afrikaans as bevrydingstaal. However, we dare not be naive about the processes which secured the development and ascendancy of Afrikaans in South Africa.

First, the single-minded political will was generated by a highly divisive sectional nationalism, born of war and persistently attracted to that idiom: from the Tweede Vryheidsoorlog to taalstryd to totale aanslag. ${ }^{2}$ Speaking in Dutch, forty years before he became Prime Minister, Dr D F Malan (1908) mockingly dismissed those who argued the merits of Dutch or Afrikaans as the language of choice, concluding that:

Such linguistic considerations ... are, to our mind, altogether irrelevant in the language battle. For us it is not a question of a more or less developed language. Even less is it a question of taste. Our national condition is too serious for that. It is in the first place - I am tempted to say it is simply and only - a volks concern. For us it is a question of existing or not existing [as a people]. ${ }^{3}$

Overriding ideologies of national unity have in many countries yielded in some measure to nuanced understandings respectful of cultural and ethnic difference in recent years. We must not confuse this 'new ethnicity' with the kind of nationalism articulated by Dr Malan which drove the Afrikaans language struggle/battle/war. South Africa could not survive eleven such singleminded nationalisms.

Secondly, this nationalism focused the direct and indirect resources of the state on one language. Because Afrikaner nationalists controlled the state for more than 40 years, the status of Afrikaans was elevated in conscious ways and funding was channelled into fostering the use of the language and ensuring its rapid development. If we reflect on this it will soon be apparent that signalling the high status of one previously underestimated language is very different in its effects from signalling the high status of nine. And simple arithmetic reveals that if the available pool of state funding does not grow (under current circumstances it is more likely to shrink) then cutting the cake into more slices reduces the possible size of each slice.

Thirdly, Afrikaans has throughout its history as an official language been strongly supported by Afrikaner social institutions and Afrikaner capital. The Afrikaans churches, for example, have provided a standing assertion of the status and dignity of the language and held Afrikaner communities together. And Afrikaner capital - a major force in the economy by the end of the 20 th century - has given ongoing support to bodies promoting Afrikaans culture and language. What is more, these resources were co-ordinated to a significant extent by the Afrikaner Broederbond, making them more effective as agents of the stryd. Again, we have to look at these elements clear-headedly, putting aside the distractions of partisan politics. The fact is that the success of Afrikaans depended in part on the dedicated support of major cultural institutions and capital and the benefits of a co-ordinating movement infused through the society. The African languages of our country are set in a different social context. There is no church denomination as a focus of, say, Xhosa identity for the majority of that speech community. African capital is in the early stages of development and has not shown a strong interest, backed by its resources, in 
any sectional identity or language struggles. And if there is co-ordination it is of a pan-African variety, underplaying the very differences which Afrikaans was able to trade on in cutting out a niche for itself. In public discourse, for example, there are pleas for the African languages in general, or, as the national Constitution $(1996,1.6(2))$ has it, 'the indigenous languages of our people.' Such plans may elicit general benevolence, but never the passionate commitment which drove the development of Afrikaans.

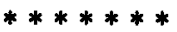

Afrikaans cannot, then, provide a workable model for the development of the African languages. However, there are striking similarities in the linguistic experiences of speakers of Afrikaans and the African languages over the years, many of them related to the disorientating experience of urbanisation and movement into a modern economy. These may yield important insights for South African language planning. Three similar patterns of experience are offered here by way of illustration.

The first concerns the language situation in schools. The setting is the Orange Free State Colony after the Anglo-Boer War under a policy of anglicisation. Botes (1941: 37) writes:

The poor little Afrikaners had ... to be taught through the medium of English by Afrikaans-speaking teachers apparently from Grade 3, even in the rural areas where the schoochildren were $100 \%$ Afrikaans. At home, father and mother and teacher and child spoke Afrikaans, but at school teacher and pupils had to speak English and spend a certain number of hours per week learning Dutch - a language which neither the teacher nor the child could master. ${ }^{4}$

Elsewhere he sums up less rhetorically:

The medium was a foreign language, the Dutch of the school was not their home language ... and there were few teachers qualified to teach Dutch. ${ }^{5}$

(Botes 1941: 34)

With a little bit of adaptation, that describes the situation for many African language speakers in $S$ Africa: the medium is English, to them a foreign language; the Xhosa (or whatever other language) of the school is not the Xhosa they speak at home; and few teachers are qualified to teach English (or in English). It is this situation which Kamwangamalu (1997: 247) is concerned about when he urges the model of Afrikaans: 'Post-apartheid South Africa does not need to look far to find a success story in mother-tongue education to emulate.' The issues must be addressed. However, the story of Afrikaans may not be as applicable as Kamwangamalu suggests.

The second familiar situation concerns language shift in the face of a loss of confidence in one's language. G S Nienaber (1933: 94f) describes the 'silencing' of Afrikaans in the face of the attractions and power of English in Natal before 1910.

The worst was when Afrikaners themselves co-operated vigorously with this process, especially the children and the women, the first influenced by the school, the second by fashion. It is reported that many urban children refused to answer their parents in Dutch when asked a question in that language. Mr AL Pretorius ... recounts how a woman with a Dutch name from Vryheid attended a meeting of a 'boer' debating society in Durban, and when she was invited by the chairman to join in replied [in English]: 'Ladies and 


\section{Gentlemen, you have to excuse me for I cannot express myself in Dutch. ${ }^{16}$}

Many colleagues in African languages departments have voiced their concern informally about similar behaviour by children in their families or communities when spoken to in an African language. Some such children, made to speak their home language to their highly educated parents, have explained apologetically to their friends that they are doing so because their parents cannot speak English - or, in the Western Cape - Afrikaans. As for the adults, I have myself witnessed what we may call 'women from Vryheid' making the same sad gesture of renunciation to show how sophisticated and socially mobile they are.

Arresting language drift demands status planning. The earliest instance I have found of an African referring to the model of Afrikaans is DM Ramoshoana (1934). Less than 10 years after the acceptance of Afrikaans as an acceptable form of Dutch to be used as an official language, he cites the case of Afrikaans as an inspiration for African languages:

The Dutch-speaking people of South Africa have pulled their Afrikaans - a baby among languages in the Union - out of the fire and have launched it as one of the most important languages in the half-continent by writing it in newspapers, magazines and books. Their ablest writers contributed articles, etc., and thus fixed its literary efficacy, and so it now faces the world as a cultural language.

Ramoshoana has clearly absorbed the status planning strategies of the Second Afrikaans Language Movement. He and Sol T Plaatje are concerned to arrest the loss of the traditional 'by cultivating a love for art and literature in the Vernacular' (Plaatje, 1930: Preface). There is no question but that the African languages must depend on a greatly increased volume of writing (fictional, popular, periodical and scholarly) if their status is to be enhanced. But that is not the only means. Nkonko Kamwangamalu (1997: 247) proposes a more interventionist strategy also based on the model of Afrikaans. He writes:

It is common knowledge that.during apartheid Afrikaans was developed and used successfully as a means of determining access to political power and economic resources. The same policy could work equally for African languages.

Kamwangamalu's 'reverse covert planning' strategy is to make 'the African languages one of the requirements for access to resources and power in the same way as English and Afrikaans have been for decades' (1997: 251). Whether this would work 'equally for African languages' is a moot point. However, the proposal signals the importance for language planning of institutionalising status.

The third familiar situation concerns linguistic standards. Like the African languages, which have undergone vital developments in the cities in contact with other languages, but which are often drawn back to the standards of the homogeneous communities of the rural areas, Dutch was much changed in the situation of colonial contact and the colonial speakers of the language were reminded of standards in the more homogeneous mother country. Edith Raidt (1994: 314) records the heroic efforts of ANE Changuion to maintain standards of metropolitan Dutch at the Cape in the 1840s. In the second edition of his book, De Nederlandse taal in Zuid-Afrika hersteld (1848), he is depressed at the carelessness and indifference of the Cape people when it comes to 'correct' use of language.

We now view the language over which we have taken so much trouble almost as a doctor 
views a terminally ill patient, the pernicious effects of whose disease may indeed be alleviated to some extent, whose certain death may indeed be delayed for a while, but of whose full recovery there is no longer any hope. ${ }^{7}$

However, all is not bleak for him:

... the cultured classes generally do their best to abandon the characteristics of Cape speech; and most of the examples given above are drawn from the low language of the uncultured classes. A person who renounces the Cape dialect is said to speak High Dutch. ${ }^{8}$

Half a century on, the situation is more contested. Ds Moorrees (1896: 284) writes that:

Where one person is zealous for 'The Afrikaans Language', another pleads for correct Dutch as it is currently written and spoken in the Netherlands, while a third demands Cape Dutch. ${ }^{9}$

Soon it is to be a battle between Afrikaans and Dutch. Afrikaans wins. But few now can share the opinion of E C Pienaar (1931: 612) that with the full recognition of Afrikaans by the Church in 1924, and by the State in 1925, 'the language war in South Africa was thus decided for good'. ${ }^{10}$

The battles described above have several times been echoed by Xhosa speaking students in my first-year tutorial classes at the University of the Western Cape. Recently initiated amadoda (men who have undergone the traditional circumcision ritual) are heated in their defence of 'correct' rural Xhosa. More worldly, city people in the class quietly argue for the urban amalgam, in one instance even pointing out to one of the new defenders of traditional culture that his 'correct' rural Xhosa is a different dialect from the 'correct' rural Xhosa which her grandmother speaks. Both parties in fact have a much wider repertoire, and enjoy playing with new urban slang. Clearly, a process similar to the Afrikaans experience can be expected for the African languages, each having to accommodate older written standards to new varieties forged through language contact and through meeting the demands of the modern world. The new National Language Bodies will have an interesting time tracking and channelling this process.

The language war EC Pienaar documents is within the ranks of Afrikanerdom. It is a battle between proponents of Afrikaans and proponents of Dutch as 'the language of culture for the Afrikaans speech community' (Ponelis 1993: 69). Before and after this war of the Second Afrikaans Language Movement, another language war periodically draws attention to itself. GS Nienaber (1950: 81) speaks baldly of 'the war against English" ${ }^{\prime 1}$ The reality is more complex. In an early document of the Taalbond (1891), an organisation to promote enthusiasm for the mother tongue, the writer (probably Prof P J G de Vos) says: 'the Taalbond is not against English, but for Dutch. ${ }^{12}$ However, five years later, his colleague in the Taalbond, Ds A Moorrees (1896), warns against the divisions that were later to occupy the Second Afrikaans Language Movement:

If we ... waste our powers on internal factionalism and point at one another the guns which should be used against the enemy, then there is little hope of gaining the desired end. ${ }^{13}$ 
In the wake of the Jameson Raid, this militantly anti-British tone and idiom is not really surprising. The learned dominee, later to become a professor, has English firmly in his sights as the enemy. Eleven years later, after the Anglo-Boer War, Professor Moorrees (1907) reverts to de Vos's position.

The libel has more than once been propounded. . . that we promote the Dutch language, in order to oppose the English language. I solemnly declare that no such thought has arisen in the minds of the executive. ... The Taalbond has in fact encouraged the study of English in the schools. ${ }^{14}$

Without questioning the integrity of Moorrees, we can say that the historical record shows the matter clearly to have been far from resolved for the Taalbond or for the society.

An equivocal attitude to English is very much a part of the model of Afrikaans throughout its twentieth century history. After the Anglo-Boer War, the Transvaal and the Orange Free State became part of British South Africa, and so English was inevitably a more powerful language than it had been before in these territories. For a while, until the practicalities began to dawn on politicians and administrators, English was the sole language of administration and English the main language of schooling. Without a sense that he was overriding a host of other considerations, the Governor of the Orange River Colony (1903) responded to petitioners for Dutch in education with the undeniable argument that:

The English Language, if not the commercial language of every part of the world, is most certainly that of South Africa, and consequently a thorough knowledge of it is of the first importance to the rising generation of this colony.

A quarter century later, Senator FS Malan (1929), writing in Ons Land, declared that 'The Dutchspeaking child must also speak good English and we must never lose sight of the value of this'. The practical value of English was (and is) undeniable. But the practical necessity of the other languages of the people for effective communication and a sense of self-worth was intuited but had yet to be fully articulated in response.

The ambiguities of attitude multiply as language politics merge with racial politics. Initially, Dutch language activists pursued statutory equality with English. The Taalbond executive sent a telegram (in English) to the National Convention which was preparing for the Union of South Africa in 1908:

The Hoofdbestuur ... humbly pray that your deliberations may be so guided as to result in a closer union not only of the Colonies and Territories of British S. Africa, but also and even more so, of their inhabitants, in heart and sentiment. The Hoofdbestuur respectfully begs to intimate that this, the closest of all possible unions, would be greatly promoted and lastingly cemented by mutual concessions between our two great European races - the English and the Dutch - in regard to their respective languages, so that these may obtain equal rights in the Legislatures, the Courts of Law, the Civil Service and the Educational Establishments of a Federated or United South Africa. (Quoted Olivier 1965: 53)

Amid the high sentiment, the goal was proposed as part of the consolidated package of racial attitudes which was increasingly to drive the dispossession of black people in the interests of 'our two great European races'. In fact, black colonists have vanished from view in the Taalbond 
telegram: they are not even seen as inhabitants of the colonies! Let us be plain that this was not an 'Afrikaans' set of attitudes: white English and Dutch colonists deflected their mutual distrust in achieving this accommodation and thereby ensnared both languages in a repressive order. They also masked rather than abandoned the Milnerite ${ }^{15}$ model of domination of one language (and language group) by another. Milnerism was to rise again in the increasing dominance of Afrikaans in the early 1970 s.

As racial politics unravel in the post-apartheid period, Afrikaans in Afrika, edited by Christo van Rensburg, attempts a nuanced discussion of Afrikaans in its relationships with English and the other South African languages. It achieves valuable reorientations. However the ambiguities regarding English persist. These lead the writers into some strange corners which may suggest to those concerned with the flowering of the African languages what they should not do. Closer analysis of the model provides warnings on three fronts. It suggests the dangers of exaggeration, of abandoning sociolinguistic knowledge, and of binary or polar thinking driven by ancient grudes and fears.

Vision is vital to language planning. Exaggeration fogs the vision. Laudably intent on stopping an unthinking drift to English, a contributor to Van Rensburg (1997: 59) produces a baffling exaggeration which may have exactly the opposite effect:

This positive attitude to English ... fails to take account of the fact that opportunities like academic training are also possible in Afrikaans at any of a great number of universities within and outside South Africa. ${ }^{16}$

Opportunities for academic training through the medium of Afrikaans are in fact declining in South Africa. Sadly, departments of Afrikaans have shrunk, and most Afrikaans universities are offering some courses through the medium of English. Further, while it is possible to study Afrikaans outside South Africa, universities abroad do not offer courses in other subjects through the medium of Afrikaans. There are, of course, major opportunities for studying through the medium of Afrikaans. The five excellent predominantly Afrikaans-medium universities in South Africa provide these. Exaggerating the international academic role of Afrikaans can only suggest that the five Afrikaans-medium universities are not good enough.

Secondly, the complexity of language and social relationships has to be explored not suppressed. Sociolinguistics gives us rich ways of understanding the complex operations of language in society, and usually provides the rationale for supporting languages under threat. It is puzzling, then, that a contributor to Van Rensburg (1997: 47) should throw sociolinguistic insights overboard in favour of prelapsarian idealism.

The language problem today in South Africa is whether non-English speaking South Africans ... are going to accept domination by English.... Such domination means that the natural language balance and language riches of South Africa are being completely disturbed. ${ }^{17}$

This prompts a series of questions. Do languages dominate people, or do people sometimes use languages as one means among many to dominate other people? Has there ever been a 'natural language balance'? The statement makes it sound as if we had such a natural balance in the recent past. Clearly, that concept is sociologically inept. And then we come to English. Does English not form part of the 'language riches of South Africa'? If not why not? 
Finally, the question of language and identity has to be explored. In one respect, at least, Afrikaans in Afrika fogs the issues with anti-English sentiment. In 1848 Changuion commented that 'an Englishman generally speaks low Cape ${ }^{18}$ (quoted Raidt 1994: 314), rather than proper Dutch, along with the lower classes. A century and a half later, a contributor to Van Rensburg (1997: 48) comments:

It is said of many Afrikaans speakers that they are English people who speak a kind of Dutch. If such a remark is true, the influence of English on Afrikaans has already taken on devastating proportions. ${ }^{19}$

A nostalgia for an (entirely fictional) cultural purity and social integrity features in this, shaped by an ancient grudge and fear of assimilation. The cultural bogey figure is the Engelsman, and the worst, most devastating fate is to take on any of his characteristics. Of course, deracination is a real enough threat in any multicultural country, but the chances of that happening are heightened by polar opposition to cross-cultural influences which might lead organically to new and vigorous identities.

If Afrikaans is not a satisfactory model, is there a satisfactory one? Probably not. Part of the problem may lie in thinking in terms of models and examples - more or less prefabricated solutions. One may then know the answers without understanding the questions. While the broad questions are evident in South Africa, they must be refined in the light of a close understanding of the current situation before they can be answered usefully. Two complex assertions may open the way to further discussion. First, all the languages of South Africa have to find their bearings and place, and grow and adapt accordingly, often under one another's influence. Language planning can guide and support this process, but only by engaging with the dynamics of a multicultural and increasingly shared society, subject to the distinctive pressures of South African modernity. Secondly, no languages are ever sociolinguistically equal. South Africa's official languages have legal equality. Giving increasing effect to that status is important. However, to pursue sociolinguistic equality is to take language planning on a wild goose chase. The challenge is to understand the current sociolinguistic situations of each of the South African languages as clearly as possible. Then, without setting one language against another, perceived language needs can be met while confidence in the value of each of the languages can be built. Only in that way is there a real chance that all South Africa's languages will progressively come into their own.

\section{REFERENCES}

BOTES, E. 1941. Die Taalmediumvraagstuk: 'n geskiedkundige oorsig van die voertaalprobleem in die O.V.S. en Transvaal met spesiale verwysing na enkel-, parallelen dubbelmediumskole. Johannesburg: Voortrekkerpers.

CONSTITUTION OF THE REPUBLIC OF SOUTH AFRICA. 1996. Pretoria: Government Printer.

GOVERNOR: ORC. 1903. Letter to petitioners, 11 November. Quoted Botes 1941: 31. 
KAMWANGAMALU, NM. 1997. Multilingualism and education policy in post-apartheid South Africa. Language problems and language planning, 21(3):234-253.

MALAN, DF. 1908. Het is ons ernst. Voorlezing voor de A.T.V., 13 August. Quoted in E C Pienaar 1931, $4 \mathrm{f}$.

MALAN, FS. 1929. Article in Ons Land, 23 April. Quoted Olivier 1965: 173.

MOORREES, A. 1896. Article in Ons Tijdschrift 1: 284. Quoted Olivier 1965: 7.

MOORREES, A. 1907. De Zuid-Afrikaan verenigd met ons land. Speech at Taalbond prizegiving, 12 March. Quoted Olivier 1965, 171.

NIENABER, GS. 1933. Honderd jaar Hollands in Natal (tot 1928). Pretoria: J H de Bussy.

NIENABER, GS. 1950. Die Afrikaanse Beweging. In Kultuurgeskiedenis van die Afrikaner. III. Cape Town: Nasionale Boekhandel. 81.

OLIVIER, JR. 1965. Die S. A. Taalbond: 1890-1965. Unpublished MEd thesis, University of Stellenbosch.

PIENAAR, EC. 1931. Taal en Poësie van die Twede Afrikaanse Taalbeweging. Cape Town: Nasionale Pers.

PLAATJE, ST. 1930. Mhudi: An epic of South African Native Life a Hundred Years Ago. Alice: Lovedale.

PONELIS, FRITZ. 1993. The Development of Afrikaans. Frankfurt am Main: Peter Lang.

RAIDT, EH. 1994. Historiese Taalkunde: Studies oor die geskiedenis van Afrikaans. Johannesburg: Witwatersrand Univ. Press.

RAMOSHOANA, D M. 1934. Letter to editor, Bantu World, 16 June. Quoted Willan 1984, 84.

SEARLE, CHRIS. 1984. Words unchained: Language and revolution in Grenada. London: Zed Books.

TAALBOND. 1891. Zullen wij nog voor onze moedertaal ijveren. Cape Town: Townshend and Son.

VAN RENSBURG, CHRISTO (Ed.). 1997. Afrikaans in Afrika. Pretoria: J L van Schaik.

WILLAN, B. 1984. Sol T Plaatje and Tswana literature: A preliminary survey. In Landeg White and Tim Couzens (Eds), Literature and society in South Africa. Pinelands: Maskew Miller Longman: 81-100.

NOTES

Quotations are translated by me unless otherwise indicated. The original Dutch or Afrikaans of all further translated quotations is given in the endnotes. 
The Second Freedom War was the Anglo-Boer War of 1899-1901. The Afrikaans language movement was characterised throughout the twentieth century as engaged in a "battle" or a "war" for the language. The word "stryd" can also mean "struggle" and the taalstryd has undergone that sea change by fortunate association with "the Struggle" for liberation which ushered in the new democratic order. "Total onslaught" valorised political oppression in the 1980s under $\mathrm{P}$ W Botha. Contemporary discussions have resurrected this vocabulary in picking up Chris Searle's (1984) metaphor, "linguistic imperialism."

Taalkundige oorwegingen ... zijn ... naar onze mening in de taalstrijd geheel misplaatst. Het is voor ons niet de kwestie van ' $n$ meer of minder ontwikkelde taal. ' $t$ Is allerminst ' $n$ kwestie van smaak. Daarvoor is onze nationale toestand te ernstig. Het is in de eerste plaats - ik wil bijna seggen het is enkel en alleen - ' $n$ volkszaak. ' $t$ Is voor ons ' $n$ kwestie van zijn of niet zijn.

Die arme Afrikanertjies moes met ander woorde deur Afrikaanssprekende onderwysers blykbaar vanaf Standerd I deur Engelsmedium geleer word, ook op die platteland waar die skoolkinders $100 \%$ Afrikaans was. Tuis praat pa en ma en meester en kind Afrikaans, maar in die skool moet meester en leerlinge Engels praat en soveel uur per week Nederlands leer wat nog die meester nog die kind kon bemeester.

Die medium was 'n vreemde taal, die Skoolhollands was nie die huistaal nie . . . en daar was maar min bekwame onderwysers om Hollands te doseer.

Die ergste is wanneer Afrikaners self hard hieraan meegewerk het, veral die kinders en die dames, die een onder die invloed van die skool, die ander van die mode. Dit word vertel hoedat baie kinders van die dorpe weier om op ' $n$ vraag in Hollands vir hulle ouers in die taal 'n antwoord te gee. Die heer AL Pretorius ... deel mee hoedat ' $n$ Vryheidse dame met ' $n$ Hollandse van ' $n$ "boere"-debatsvereniging op Durban bygewoon het, en toe sy deur die voorsitter gevra is om ook iets te sê antwoord: "Ladies and Gentlemen, you have to excuse me for I can't express myself in Dutch."

Thans beschouwen wij de taal, waaraan wij onze moeite besteden, gelijk een geneesheer een ongeneesliken lijder, wiens kwaal in hare onverderflijke uitwerkingen wel enigsins gematigd, wiens gewissen dood wel eenigen tijd kan vertraagd worden, maar op wiens volkomen herstel niet meer te hopen valt.

... [dat] de beschaafde klasse overal haar best doet om het kenmerkende der Kaapsche spraak af te leggen; en dat vele van de hierboven opgegeven voorbeelden in de platte taal der onbeschaafde klassen thuis hooren. Wie de Kaapsche tongval verzaakt wordt gezecht hoog Hollandsch te spreken.

Waar de één ijvert voor 'Di Afrikaanse Taal', pleit een ander voor het zuiwer Hollandsch dat nu in Nederland geschreven en gesproken word, terwijl een derde een Kaapsch-Hollandsch wil ....

... die taalstryd in Suid-Afrika [is] dus vergoed beslis. ...

die stryd teen Engels

"de Taalbond willen niet tegen Engelsch, maar voor Hollandsch" (Zullen wij nog voor onze moedertaal ijveren? 1891.4).

Indien wij ... door onderlinge partijzucht onze krachten laten verteren en de wapens die tegen den vijand moeten gekeerd zijn, op elkander richten, dan is er weinig hoop op een gewenschten uitslag.

De laster was meermalen geuit ... dat wij, met de bevordering der Hollandse taal, beogen de Engelse taal tegen te werken. Spreker verklaarde dat een dergelijke gedachte nooit bij het bestuur was opgekomen... De Taalbond had reeds de beoefening van het Engels by het onderwijs aangemoedigd.

Sir Alfred Milner was the British administrator of the conquered republics immediately after the AngloBoer War. He pursued an aggressive policy of anglicisation. As he was an exceedingly influential figure, his policies lived on as Milnerism. The term is applied here by analogy to the aggressive afrikaansisation policies and practices of the National Party government after 1948. 
16 Hierdie positiewe ingesteldheid teenoor Engels . . . hou nie rekening daarmee dat geleenthede soos akademiese skoling aan een van 'n groot aantal universiteite binne en buite Suid-Afrika ook in Afrikaans moontlik is nie.

17 Die taalprobleem vandag in Suid-Afrika is of die nie-Engelsprekende Suid-Afrikaners ... oorheersing deur Engels gaan aanvaar. ... So 'n oorheersing beteken dat die natuurlike taalbalans en taalrykdom in Suid Afrika heeltemal versteur word.

18 Een Engelschman spreekt doorgaans plat Kaapsch.

19 Daar word van baie Afrikaanssprekendes gesê dat hulle Engelse is wat 'n soort Nederlands praat. Indien so ' $n$ uitlating waar is, het die invloed van Engels op Afrikaans reeds verwoestende afmetings aangeneem.

\section{Biographical note}

Professor Stanley Ridge is in the English Department at the University of the Western Cape (e-mail: ridge@adept.co.za). 